\title{
Diana Brydon and Marta Dvořák, eds., Crosstalk: Canadian and Global Imaginaries in Dialogue
}

John Thieme

\section{Q OpenEdition}

1 Journals

Electronic version

URL: https://journals.openedition.org/ces/5914

DOI: 10.4000/ces.5914

ISSN: 2534-6695

Publisher

SEPC (Société d'études des pays du Commonwealth)

\section{Printed version}

Date of publication: 1 April 2013

ISSN: 2270-0633

Electronic reference

John Thieme, "Diana Brydon and Marta Dvořák, eds., Crosstalk: Canadian and Global Imaginaries in Dialogue", Commonwealth Essays and Studies [Online], 35.2 | 2013, Online since 17 April 2021, connection on 23 July 2021. URL: http://journals.openedition.org/ces/5914 ; DOI: https://doi.org/ $10.4000 /$ ces.5914

This text was automatically generated on 23 July 2021 .

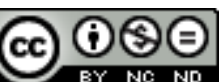

Commonwealth Essays and Studies is licensed under a Licence Creative Commons Attribution - Pas d'Utilisation Commerciale - Pas de Modification 4.0 International. 


\title{
Diana Brydon and Marta Dvořák, eds., Crosstalk: Canadian and Global Imaginaries in Dialogue
}

\author{
John Thieme
}

\section{REFERENCES}

Diana Brydon and Marta Dvořák, eds. Crosstalk: Canadian and Global Imaginaries in Dialogue. Waterloo, ON: Wilfrid Laurier UP, 2012. viii, 321 p. ISBN (hb): 9781554582648. $\mathrm{CA} \$ 85$

1 This stimulating collection of essays had its origins in a workshop entitled "Voice and Vision: Situating Canadian Culture Globally," held at the Sorbonne Nouvelle in 2008. Conference volumes invariably run the risk of following Stephen Leacock's horseman by "rid[ing] madly off in all directions" and here this endemic hazard has been increased by the redirection of emphasis from the workshop's focus on "voice and vision" to "crosstalk." Thankfully, though, ample cross-references have made Crosstalk a far more unified collection than most conference-generated volumes. In the spirit of the book's title, the contributors have clearly engaged in a considerable amount of post-workshop dialogue and, thanks to this and the careful introduction, the collection does a fine job of answering the questions posed by the editors at the outset. These questions gravitate around the need to renegotiate meaning and find new conceptual paradigms at a time when, in the age of globalization, consensual notions of what constitutes Canadianness are diverging.

2 Cooperative intercultural exchange is very much to the fore throughout Crosstalk, reflecting, as one of the authors puts it in a note, "the increasing emphasis placed on collaborative and interdisciplinary scholarship by funding bodies such as the Social Science and Humanities Research Council." This may point towards a new orthodoxy, but it is a welcome shift away from the privileging of the lone man [sic] of letters 
towards a partnership model of cultural inquiry that interrogates dominant postEnlightenment ideologies; and joint work ("crosstalk"?) dovetails neatly with the endeavour to find broad-based transcultural models of investigation that is at the heart of this collection. Sometimes, though, one has the sense that the receipt of funding for collaborative research may have constrained the work of Canadian scholars, whose box-ticking appears, on occasions, to have shackled rather than unleashed free-flowing innovative crosstalk. That said, the majority of the pieces in the collection speak to the healthiness of the initiatives promoted by SSHRC and other Canadian agencies that have fuelled dialogue between public policy and academic investigation.

3 The papers by non-Canadian contributors seem freer to go their own way. Pilar CuderDomínguez and Sandra Regina Goulert Almeida both provide illuminating insights into the work of Dionne Brand: in Cuder-Domínguez's case by comparing What We All Long for with Madeleine Thien's Certainty and focusing on the ethics and politics involved in the two texts' representation of postmodern visual art; in Almeida's case by demonstrating how Brand's work has taken Canadian writing in new directions by unsettling notions of what it might be through providing "visions of the present-day cosmopolitan nation and the new geopolitical spaces originated by the continuous emergence of transit and diasporic movements in our contemporary globalized world." Jane Urquhart's fiction is also the subject of two fine papers - on literary landscapes: Claire Omhovère brings her expertise on spatial geographies to bear on Urquhart's The Whirlpool, while Catherine Lanone shows how the "ghostwriting" of Wuthering Heights in Changing Heaven generates a very different meteorological and cultural climate for Canada. Another pair of excellent complementary essays offer close analyses of texts, while also expanding outwards to open up windows onto the book's main agendas. Daniel Coleman's reading of David Chariandy's Soucouyant and Lee Maracle's Daughters are Forever argues for a reassessment of the possibilities associated with melancholia by demonstrating how the two novels discussed counterbalance victim-dominated responses to trauma with a spiritual world-view that works to "heal its scars"; and, in so doing, directs attention away from "secular, Euro-American epistemologies" that focus exclusively on the psychology of domination. Ric Knowles gives a circumstantial account of the work of Monique Mojica and the Chocolate Woman Workshops, which, without labouring its broader significance, serves as a blueprint for the transformative possibilities inherent in contemporary Native performance culture.

Other highlights include Olive Senior talking about her use of voice and vision and her development as a writer. As part of this, she explains how her absorption in the persona of a country girl speaking in the Jamaican vernacular of her African ancestors (in her story "Ballad") became a breakthrough moment for her - a moment that released her to write in whatever voices were appropriate for her varied characters. A world away from Canada, this essay nevertheless speaks to the plurality of voices to be found in contemporary Canadian writing and lingers longer in the mind than some of the more obviously Canadian pieces. Christine Lorre-Johnston provides a nuanced discussion of Robert Lepage's Dragons' Trilogy; and Chelva Kanaganayakam is similarly discriminating in his response to ways in which the notion of "home" is refashioned in the South Asian diaspora.

5 Ultimately, though, the success of this timely collection owes much to the work of the two editors. In addition to contributing inspiring essays of their own - Marta Dvořák analyses a kaleidoscopic array of "metafiction in mutation"; Diana Brydon gives a case- 
study of the Hérouxville debates to argue for "the need to read within translocal terms" - both have clearly put in long hours to ensure that the book's attempt to broaden the models used to debate Canadian imaginaries has become a significant intervention. The net result is impressive and one comes away from Crosstalk feeling that the multiple directions taken by the individual authors (analogous to Leacock's horseman?) have been along routes that have converged at a common crossroads.

\section{AUTHORS}

\section{JOHN THIEME}

John THIEME is a Senior Fellow at the University of East Anglia and previously held Chairs at the University of Hull and London South Bank University. His books include Derek Walcott (1999), PostColonial Con-Texts (2001), Post-Colonial Studies: The Essential Glossary (2003) and R. K. Narayan (2007). He edited The Journal of Commonwealth Literature from 1992 to 2011 and is General Editor of the Manchester University Press Contemporary World Writers Series. 